\title{
Analisis Pelaksanaan Akad Pembiayaan Murabahah di Baitul Maal Wat Tamwil Insan Samawa Dalam Perspektif Ekonomi Syariah
}

\author{
Oleh: Feri Irawan \\ Sekolah Tinggi Agama Islam Nahdlatul Wathan Samawa Sumbawa Besar, NTB \\ Email: irawanferi23@gmail.com
}

\begin{abstract}
Abstrak: Dalam pembiayaan murabahah fungsi BMT adalah sebagai penjual barang untuk kepentingan nasabah. Dengan cara membeli barang yang diperlukan nasabah dan kemudian menjualnya kembali kepada nasabah dengan harga jual yang setara dengan harga beli ditambah keuntungan BMT. Dan BMT harus memberitahukan secara jujur harga pokok barang berikut biaya yang diperlukan dan menyampaikan semua hal yang berkaitan dengan pembelian barang kepada nasabah. Disini penulis akan membahas BMT Insan Samawa yaitu mengenai pelaksanaan akad pembiayaan murabahah dalam perspektif ekonomi syariah, ketertarikan penulis ini dikarenakan adanya rasa ingin tahu secara lebih jelas dan lebih rinci tentang pembiayaan dengan akad murabahah di BMT Insan Samawa, dan apakah yang membedakan dalam pelaksanaan pembiayaan dengan akad murabahah di BMT Insan Samawa dengan lembaga keuangan syariah lainya.
\end{abstract}

Kata Kunci: Analisis, Pembiayaan Murabahah, BMT, Persefektif Ekonomi Syariah

\section{PENDAHULUAN}

Baitul Maal Wat Tamwil Insan Samawa merupakan salah satu lembaga keuangan yang dalam melaksanakan kegiatan usahanya berdasarkan prinsip- prinsip syariah. Yang memiliki fungsi menghimpun dana dan menyalurkan dana kepada masyarakat. Kegiatan menghimpun dana disebut funding dan kegiatan menyalurkan dana disebut financing atau lending. (Brosur BMT Insan Samawa).

Dalam kegiatan menyalurkan dananya dalam bentuk pembiayaan, BMT Insan Samawa menggunakan akad bagi hasil (mudharabah) dan akad jual beli (murabahah).Pembiayaan yang paling banyak di salurkan adalah pembiayaan berbasis jual beli dengan akad murabahah.

Menurut Heri Sudarsono (2004:62), akad murabahah adalah jual-beli barang pada harga asal dengan tambahan keuntungan yang disepakati antara pihak BMT dan nasabah. Dalam murabahah penjual menyebutkan harga pembelian barang kepada pembeli 
kemudian ia mensyaratkan atas laba dalam jumlah tertentu. Beberapa ketentuan harus dipenuhi dalam melaksanakan akad murabahah agar transaksi akad tersebut terhindar dari riba dan sesuai dengan syariah. Salah satunya adalah syarat barang yang diakadkan dalam hal ini adalah barang yang diperjual belikan bukan barang haram.

\section{LANDASAN TEORI DAN KERANGKA BERFIKIR}

\section{A. Tinjauan Pembiayaan Murabahah}

Menurut M. Syafi'i Antonio menjelaskan bahwa pembiayaan merupakan salah satu tugas pokok bank yaitu pemberian fasilitas dana untuk memenuhi kebutuhan pihak-pihak yang merupakan deficit unit.

Menurut Muhammad (2005:17), pembiayaan adalah pendanaan yang diberikan oleh suatu pihak kepada pihak lain untuk mendukung investasi yang telah direncanakan, baik dilakukan sendiri maupun lembaga.

Murabahah adalah jual beli barang pada harga asal dengan tambahan keuntungan yang disepakati. Dalam Al-Murabahah, penjual harus memberi tahu harga produk yang dibeli dan menentukan suatu tingkat keuntungan sebagai tambahan. (M. Antonio Syafi'i, 2001:101)

a. Murabahah menurut ahli Fiqh dan praktisi:

Menurut Wahbah Az-Zuhaili (2011:357), dalam kitabnya mengatakan jual beli murabahah, yaitu menjual barang sesuai dengan harga pembelian, dengan menambahkan keuntungan tertentu. Sedangkan menurut Sayyid Sabiq, (2008:145), Murabahah adalah penjualan dengan harga pembelian barang berikut untung yang diketahui.

b. Murabahah menurut para ahli praktisi keuangan syariah sebagai berikut :

1. Sparta, Menjelaskan bahwa Murabahah adalah transaksi penjualan barang dengan menyatakan harga perolehan dan keuntungan (margin) yang disepakatioleh penjual dan pembeli. Dalam hal ini, bank syariah dapat bertindak sebagai penjual dan pembeli. Sebagai penjual, bank melakukan penjualan barang kepada nasabah (pembeli).

2. Muhammad Nadratuzzaman (2013:117), yaitu jual beli dengan dasar harga beli ditambah ongkos dan laba yang diinginkan.

3. Muhammad (2015:23), memberikan pengertian yang disandarkan pada perkataan Ibnu Qudamah dalam bukunya Mughni 4/280 mendefinisikan: Murabahah adalah 
menjual dengan harga asal ditambah dengan margin keuntungan yang telah disepakati.

4. Widodo (2014:409), murabahah adalah Jual-beli yang mana si penjual berkewajiban menyampaikan harga jualnya kepada si pembeli ditambah keuntungan yang telah disepakati antara si penjual dengan si pembeli.

Murabahah merupakan produk jual beli dengan harga asal ditambah dengan margin keuntungan yang telah disepakati. Produk ini memudahkan nasabah untuk mendapatkan barang yang dibutuhkannya dengan biaya yang relatif lebih mudah, yaitu dengan margin (keuntungan) yang telah disepakati antara Bank Syariah dengan nasabah. Produk ini sangat membantu nasabah yang membutuhkan barang dimana pada saat membutuhkan barang tersebut nasabah tidak memiliki uang tunai, disini Bank Syariah dapat membantunya dengan produk pembiayaan murabahah, nasabah memenuhi kewajibannya pada saat tertentu yang telah disepakati bersama. (Adiwarman A Karim, 2008:98)

\section{B. Rukun dan Syarat Murabahah}

a. Rukun dan Syarat Murabahah

Murabahah mempunyai rukun dan syarat yang harus dipenuhi sehingga jual beli dapat dikatakan sah oleh syara'. Oleh karena murabahah adalah salah satu jenis jual beli, maka rukun murabahah adalah seperti rukun dan syarat jual beli pada umumnya yaitu: (H. Sulaiman Rasjid, 2013: 279 - 281)

1. Penjual dan pembeli syarat - syaratnya:

a. Berakal, agar dia tidak terkecoh. Orang yang gila atau bodoh tidak sah jual belinya

b. Dengan kehendak sendiri (bukan di paksa)

c. Tidak mubazir (pemboros)

d. Balig (berumur 15 tahun keatas/ dewasa)

2. Uang dan benda yang dibeli, syarat - syaratnya:

a. Suci, barang najis tidak sah dijual dan tidak boleh dijadikan uang untuk dibelikan, seperti kulit binatang atau bangkai yang belum disamak. 
b. Ada manfaatnya

c. Barang itu dapat diserahkan. Tidak sah menjual suatu barang yang tidak dapat diserahkan kepada yang membeli, misalnya ikan dalam laut.

d. Barang tersebut merupakan kepunyaan si penjual, kepunyaan yang di wakilinya, atau yang mengusahakan.

e. Barang tersebut diketahui oleh si penjual dan pembeli: zat, bentuk, kadar (ukuran), dan sifat - sifatnya jelas sehingga antara keduanya tidak akan terjadi kecoh - mengecoh.

3. Lafas ijab dan qabul

a. Lafas yaitu perkataan penjual, sedangkan

b. Qabul adalah ucapan si pembeli

Sedangkan menurut M. Antonio Syafi'i, (2001:102) syarat- syarat murabahah adalah sebaai berikut:

1. penjual memberi tahu biaya modal kepada nasabah

2. Kontrak pertama harus sesuai dengan rukun yang ditetapkan

3. Kontrak harus bebas dari Riba

4. Penjual harus menjelaskan kepada pembeli bila terjadi cacat atas barang sesudah pembelian

5. Penjual harus menyampaikan semua hal yang berkaitan dengan pembelian, misalnya jika pembelian dilakukan secara hutang.

Secara prinsip jika syarat yang dijelaskan diatas tidak dipenuhi, pembeli memiliki pilihan:

1. Melanjutkan pembelian seperti apa adanya

2. Kembali kepada penjual dan menyatakan ketidaksetujuan atas barang yang dijual

3. Membatalkan kontrak

\section{Landasan Hukum Murabahah}

a. Firman Allah Swt dalam Al- Qur'an dan terjemahan antara lain:

1. QS Surah An- Nisa' [4] 29: 


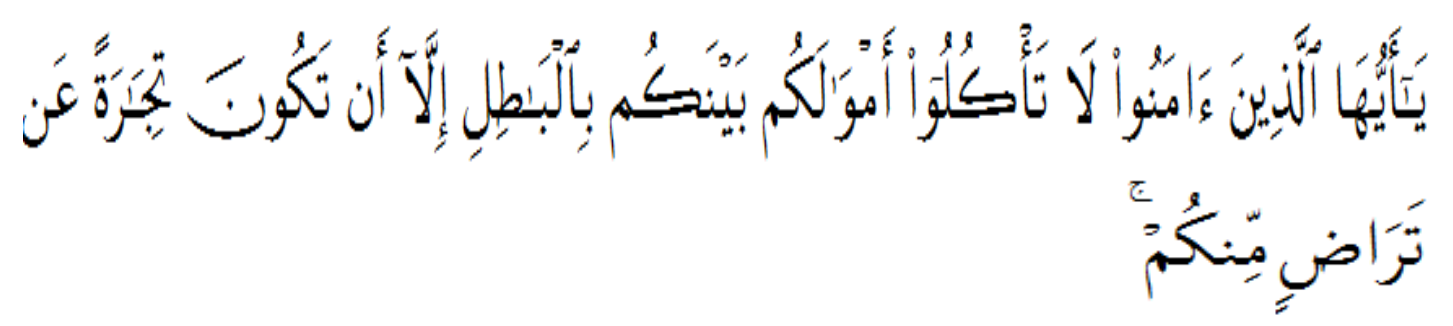

Artinya: Hai orang yang beriman! Janganlah kalian saling memakan (mengambil) harta sesamamu dengan jalan yang batil, kecuali dengan jalan perniagaan yang berlaku dengan sukarela di antaramu.(Qs. An - Nisa';29)

Ayat ini menerangkan hukum transaksi secara umum, lebih khusus kepada transaksi perdagangan, bisnis jual beli. Sebelumnya telah diterangkan transaksi muamalah yang berhubungan dengan harta, seperti harta anak yatim, mahar, dan sebagainya.

2. QS Surah Al - Baqarah 275

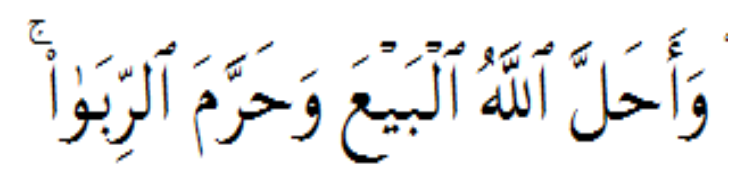

Artinya: Allah telah menghalalkan jual beli dan mengharamkan riba.(Qs. AlBaqarah:275)

Ayat diatas menegaskan bahwa telah dihalalkan jual-beli dan diharamkan riba. Orang-orang yang membolehkan riba dapat ditafsirkan sebagai pembantahan hukum-hukum yang telah ditetapkan oleh Allah Yang Maha Mengetahui lagi Maha Bijaksana. Riba yangdahulu telah dimakan sebelum turunya firman Allah ini, apabila pelakunya bertobat, tidak ada kewajiban untuk mengembalikannya dan dimaafkan oleh Allah. Sedangkan bagi siapa saja yang kembali lagi kepada riba setelah menerima larangan dari Allah, maka mereka adalah penghuni neraka dan mereka kekal di dalamnya. 
3. Qs Surah Al- Mai'dah [5] 2:

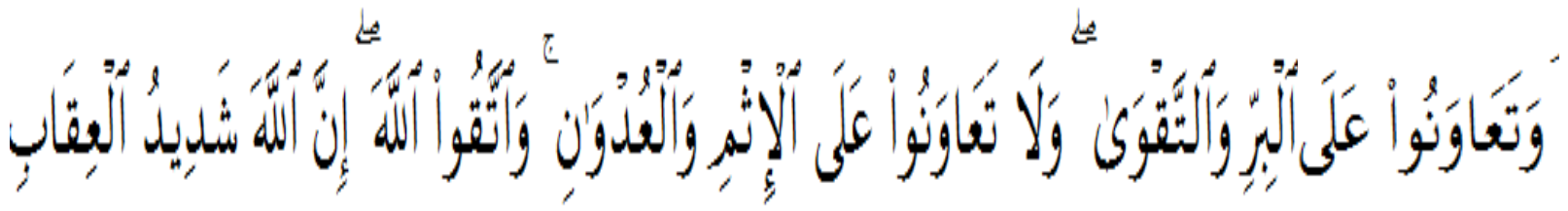

Artinya : Dan tolong-menolonglah kamu atas dasar kebajikan dan takwa, dan jangan tolong-menolong dalam berbuat dosa dan permusuhan. Dan bertawakallah kamu kepada Allah sesungguhnya Allah amat berat siksa-Nya. (Qs. Al-Mai'dah:2)

Ayat diatas menerangkan bahwasannya Allah memerintahkan para hamba-

Nya yang beriman agar saling tolong menolong dalam melakukan berbagai kebajikan. Dan itulah yang dimaksud dengan kata al-birr (kebaktian). Dan tolong menolonglah kalian dalam meninggalkan berbagai kemungkaran. Dan inilah yang dimaksud dengan takwa (dalam arti sempit, yakni menjaga untuk tidak melakukan kemungkaran).

\section{METODE PENELITIAN}

\section{A. JENIS PENELITIAN}

Penelitian yang dilakukan ini adalah penelitian lapangan (field research). Objek utamanya adalah data yang diperoleh di BMT Insan Samawa, baik sejarah berdirinya maupun kegiatan usahanya. Ide pentingnya adalah bahwa peneliti berangkat kelapangan untuk mengadakan pengamatan tentang sesuatu fenomena dalam suatu keadaan alamiah. Dalam hal demikian maka penelitian ini terkait dengan pengamatan berperan serta.

Tujuan penelitian kasus dan lapangan adalah mempelajari secara intensif tentang latar belakang keadaan sekarang dan interaksi lingkungan sesuatu unit sosial: individu, kelompok, lembaga atau masyarakat. Penelitian kasus adalah penelitian mendalam mengenai unit sosial tertentu yang hasilnya merupakan gambaran lengkap dan terorganisasi baik mengenai unit. (Murti Sumarni dan Salamah, 2006 : 48)

Data yang dikumpulkan berupa kata-kata, gambar dan bukan angka-angka. Laporan penelitian akan berisi kutipan-kutipan data untuk memberi gambaran penyajian laporan tersebut. Data yang diperoleh mungkin berasal dari wawancara, catatan lapangan, foto, rekaman, dokumen pribadi, catatan atau memo, dan dokumen asli lainnya. 
Pertanyaan penelitiannya dengan katatanya (?)"mengapa", "alasan apa”, dan "bagaimana terjadinya" yang akan dimanfaatkan peneliti. (M. Jafar Anwar, 2016 : 65).

Ciri-ciri dominan dalam penelitian kualitatif yaitu: (M. Jafar Anwar, 2016 : 66-68)

1. Sumber datanya langsung berupa data situasi alami dan peneliti adalahinstrumen kunci

2. Bersifat deskriptif

3. Lebih menekankan pada makna proses ketimbang hasil

4. Analisis data induktif

5. Makna merupakan perhatian utama dalam pendekatan penelitian

\section{B. PENDEKATAN PENELITIAN}

Pendekatan adalah cara yang digunakan untuk mengadakan penelitian" (Suharsimi Arikunto, 2006:25). Pendekatan yang digunakan dalam penelitian ini adalah pendekatan kualitatif. Pendekatan tersebut digunakan untuk mendapatkan data mendalam mengenai pelaksanaan pembiayaan dengan akad murabahah. Data yang dicari tersebut disajikan dalam bentuk rangkaian kalimat, wacana, dan ilustarsi. Dengan menggunakan pendekatan kualitatif penelitian dapat terarah lebih tepat sesuai dengan tujuan penelitian.

\section{TEMPAT DAN WAKTU PENELITIAN}

Adapun lokasi penelitian yaitu di BMT Insan Samawa yang berdiri pada tanggal 31 Oktober 2015, bertempat di jalan Cendrawasih NO. 30 Kelurahan Brang Biji, Sumbawa. Pendirian BMT Insan Samawa dilatarbelakangi keinginan para pendiri untuk mewujudkan Lembaga Keuangan yang murni Syari'ah, dengan melandaskan operasional transaksi berbasis konsep muamalah yang dituntunkan Rasulullah SAW.

Peneliti memilih lokasi ini karena BMT Syari'ah Insan Samawa merupakan salah satu lemabaga keuangan mikro syari' ah yang memiliki sistem pembiayaan yangdiperoleh dengan mudah dan cepat.

Penelitian ini dilakukan kurang lebih selama 2 bulan yaitu dari tanggal 12 bulan Oktober sampai tanggal 12 bulan Desember 2018 yang dilaksanakan di Baitul Maal Wat Tamwil Insan Samawa. 


\section{HASIL PENELITIAN DAN PEMBAHASAN}

\section{Prosedur Akad pembiayaan murabahah di BMT Insan Samawa}

Berikut adalah proses pengajuan murabahah bagi nasabah baru BMT Insan Samawa berdasarkan keterangan manajer operasional, sebagai berikut:

- Nasabah datang ke BMT menyampaikan maksud dan tujuan datang ke BMT (jika mengajukan pembiayaan akan ditanyakan untuk apa). Jika yang diajukan adalah pembiayaan murabahah maka harus sesuai dengan aturan yang telah ditetapkan BMT.

- Agar dapat diproses lembaga maka nasabah harus menjadi anggota (menyetor simpanan pokok, wajib, dan mengisi buku keanggotaan)

- Nasabah kemudian mengisi form pengajuan pembiayaan dilengkapi data pribadi (KTP, KK dan lainnya).

- Setelah form dan persyaratan diisi kemudian diproses oleh bagian pembiayaan untuk di cek pengajuannya, apakah sudah sesuai dengan ketentuan BMT.

- BMT melakukan silaturahmi serta melakukan verifikasi data ke nasabah (catatan: verifikasi dilakukan melalui proses antrian berkas sesuai data yang masuk). Dalam verifikasi ini BMT melakukan cek ulang tempat tinggal nasabah dan lainnya serta kebutuhan terkait barang yang dipesan. Untuk menyesuaikan antara kebutuhan dan kemampuan termasuk manfaat barang-barang yang dipesan.

- Proses berikutnya ketika lolos verifikasi BMT yaitu melakukan penyediaan barang yang dibutukan nasabah. BMT dalam hal ini akan mencarikan barang yang sesuai pesanan.

- Tahap pencairan awal melalui pengecekan barang pesanan dengan barang yang tersedia di stokis sembakao BMT Insan Samawa, jika tidak ada maka dicarikan disupliyer lain yang menyediakan barang.

- Ketika barang yang dibutuhkan sudah sesuai kriteria yang dinginkan nasabah maka BMT akan membayar lunas kepada pemasok (terutama untuk barangbarang baru). 
- Barang yang sudah dibayar BMT kemudian dikirim oleh pemasok ke nasabah (semua biaya operasional yang menanggung nasabah atau pihak nasabah yang mengambil ke supliyer).

- Setelah selesai disepakati, maka masuk proses akad jual beli murabahah dan kesepakatan dalam penyelesaian angsuran.

Gambar 1.1

Skema murabahah tanpa wakalah

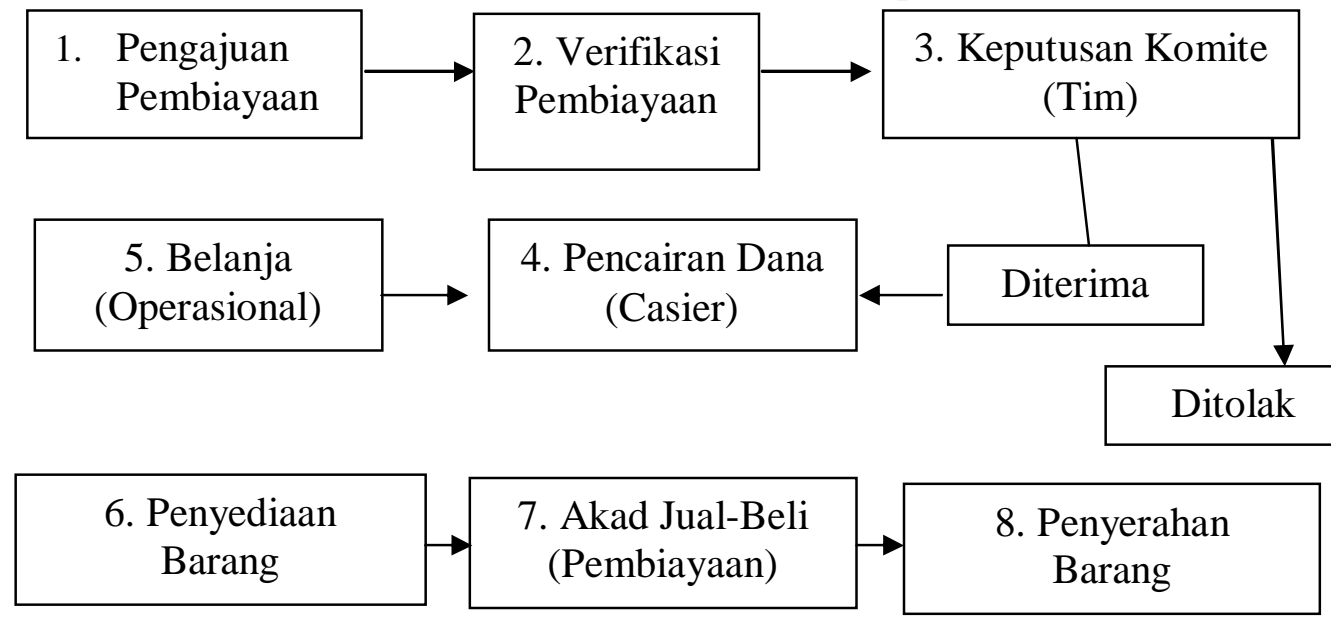

Dari gambar diatas dijelaskan bahwa :

1. Saat proses pengajuan nasabah ditangani oleh manajer operasional

2. Adapun verifikasi data pada bagian pembiayaan

3. Keputusan diterima/ ditolak dalam proses murabahah ditentukan oleh komite (Pembiayaan, Operasional, Manajer dan Casier)

4. Sedangkan untuk pencairan dana pembelian barang dilaksanakan bagian operasional

5. Setelah menerima uang bagian operasional membelanjakan barang pesanan

6. Apabila barang sudah diterima dan sesuai dengan pesanan awal bagian operasional melakukan akad jual beli murabahah. Selanjutnya bagian operasional menyerahkan barang kepada nasabah

\section{Pelaksanaan Akad Pembiayaan Murabahah di BMT Insan Samawa}

Dalam fiqh muamalah untuk setiap akad pembiayaan telah diatur mengenai ketentuan rukun dan syarat, baik akad syirkah maupun jual beli,seperti halnya dengan akad jual beli murabahah. Untuk di Indonesia sendiri akad-akad pembiayaan syariah telah diatur dalam ketentuan Fatwa DSN MUI. Ketentuan-ketentuan tersebut harus 
dipenuhi agar akad-akad pembiayaan dianggap sah dan sejalan dengan ketentuanketentuan syariah. Akad murabahah dalam Fatwa DSN-MUI Nomor04/DSNMUI/IV/2000, didefinisikan dengan menjual suatu barang dengan menegaskan harga belinya kepada pembeli dan pembeli membayarkannya dengan harga yang lebih tinggi sebagai laba. Fatwa tersebut mengatur beberapa persyaratan pembiayaan murabahah, antara lain sebagai berikut:

1. BMT menyediakan dana pembiayaan yang disalurkan berdasarkan perjanjian jual beli amanah.

2. Jangka waktu pembayaran harga oleh anggota kepada BMT ditentukan berdasarkan kesepakatan BMT dan anggota.

3. BMT selaku penjual harus memberitahu harga produk (harga perolehan)yang ia beli dan menentukan suatu tingkat keuntungan (dalam nominalsebagai tambahan).

4. BMT dapat membiayai sebagian atau seluruh harga pembelian barang yang disepakati.

5. Dalam hal BMT mewakilkan (wakalah) kepada anggota untuk membeli barang, maka akad murabahah harus dilakukan setelah barang secara prinsip menjadi milik BMT.

6. BMT boleh meminta anggota untuk menyediakan agunan selain barang yang dibiayai BMT.

7. Kesepakatan margin harus ditentukan satu kali pada awal akad dan tidak berubah selama periode akad.

Untuk pembiayaan murabahah bil wakalah dalam fatwa DSN MUI Nomor 04/DSN-MUI/IV/2000 sebagaimana telah dijelaskan di atas. Jika BMT menggunakan akad wakalah untuk memberikan kuasanya kepada anggota untuk membeli barang, maka akad murabahah hanya bisa dilaksanakan ketika barang sudah ada dan sah menjadi milik BMT atau ketika proses wakalah selesai. 


\section{Gambar 1.2}

Skema murabahah bil wakalah:

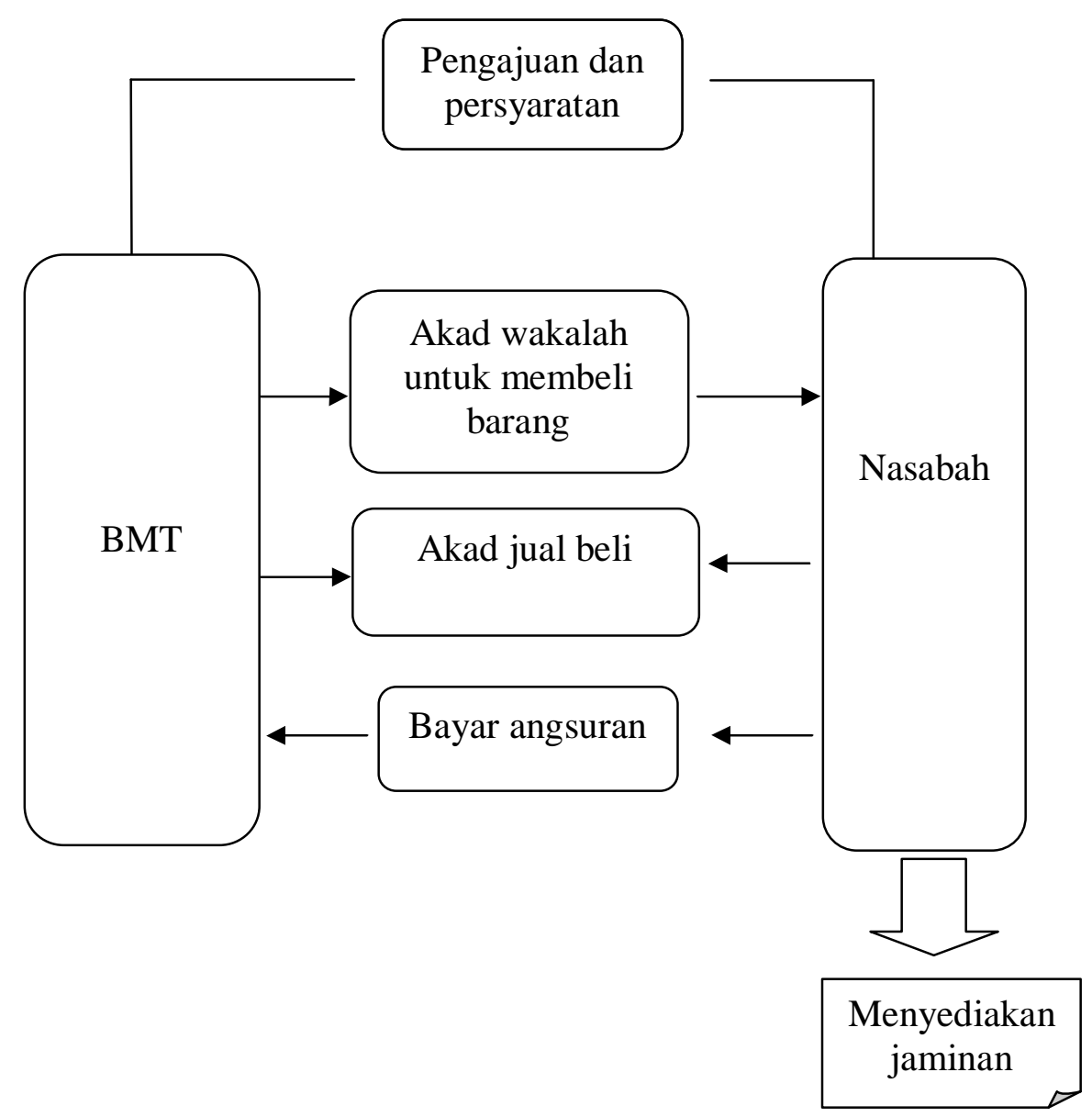

Penjelasan dari skema diatas dijelaskan sebagai berikut :

a. Nasabah mengajukan pembiayaan murabahah bil wakalah kepada BMT dengan membawa persyaratan.

b. BMT mewakilkan pembelian barang kepada nasabah

c. Nasabah membeli barang dari suplier atas nama BMT

d. Setelah akad wakalah selesai selanjutnya akad jual beli secara kredit

e. Nasabah membayar angsuran kepada Lembaga Keuangan Syariah / BMT. 
Jadi, dari penjelasan diatas dapat diketahui bahwa, BMT Insan Samawa dalam melaksanakan prosedur akad murabahah bil wakalah, sesuai dengan Fatwa DSN MUI 04/DSN-MUI/ IV/2000 tentang murabahah. Karena praktek murabahah bil wakalah yang terjadi jelas adanya objek barang dan kejelasan akad.

Peneliti menanyakan kepada nasabah pembiayaan murabahah di BMT Insan Samawa terkait pembiayaan dengan akad wakalah, disini peneliti melakukan wawancara dengan ibu Marni selaku nasabah BMT Insan Samawa, beliau memaparkan bahwa:

"Pembiayaan saya adalah pembiayan sayur-sayuran, seperti cabai, tomat, kangkung dan lain-lain. BMT memberikan kepercayaan kepada saya untuk membeli sayur-sayuran itu sendiri dengan akad wakalah, kemudian saya memberikan nota pembelian barang saya kepada BMT”. (wawancara dengan Ibu Marni)

Peneliti juga menanyakan kepada nasabah pembiayaan murabahah di BMT Insan Samawa terkait pembiayaan tanpa wakalah, yaitu Bapak Alhamra, beliau menuturkan bahwa:

"Pembiayaan murabahah di BMT Insan Samawa pencairan dananya dalam bentuk barang bukan uang yang dilakukan di stokis BMT Insan Samawa”. (wawancara dengan Bapak Alhamra)

Pernyataan yang sama kembali di tuturkan oleh Ibu mega,

"Berdasarkan apa yang saya alami selama menjadi nasabah di BMT Insan Samawa, pembiayaan yang diberikan oleh pihak BMT memang dalam bentuk uang bukan barang”. (wawancara dengan Ibu Mega)

Bapak Alhamra kembali menegaskan bahwa:

"Jika saya menginginkan pembiayaan dalam bentuk uang pihak BMT Insan Samawa menjelaskan kepada saya bahwa jika jenis pembiayaan saya adalah barang konsumtif dan BMT mempunyai stok barang sendiri di stokis BMT karena jika pembiayaan saya diberikan dalam bentuk uang pihak BMT khawatir di salah gunakan”. (wawancara dengan Bapak Alhamra)

Jadi dapat disimpulkan dari beberapa persepsi nasabah diatas terkait edukasi syariah yang dilakukan BMT. BMT Insan Samawa secara intensif atau terus menerus melakukan pemahaman syariah saat nasabah datang mengajukan pembiayaan pada lembaga. 
Sehingga dalam benak nasabah ketika datang ke BMT Insan Samawa yang ingin dilakukan adalah pemesanan barang, baik untuk kebutuhan konsumtif maupun produktif, karena apabila yang diajukan pinjaman dana secara otomatis tertolak atau dialihkan dalam bentuk akad pembiayaan lain.

Peneliti juga melakukan wawancara dengan sekretaris BMT Insan Samawa yaitu bapak Alif Hayat, mengenai penggunaan akad wakalah di BMT, beliau menjelaskan bahwa:

"Jika BMT menggunakan akad wakalah kepada anggota untuk membeli barang maka akad murabahah hanya bisa dilaksanakan ketika barang sudah ada dan sah menjadi milik BMT. Karena dengan adanya akad wakalah, menjadikan skim ini berbeda dari skim murabahah dalam konsep fiqh, karena terjadi pelimpahan kekuasaan pengadaan barang dari penjual kepada pembeli”. (wawancara dengan Bapak Alif Hayat)

Beliau juga kembali menuturkan bahwa:

"Dalam praktek pembiayaan murabahah yang terjadi di BMT Insan Samawa pelaksanaan akad murabahah dan wakalah dilakukan dalam waktu yang berbeda, yaitu penyampaian akad wakalah secaralisan yang kemudian dilanjutkan Setelah terjadi akad wakalah dan objek murabahah secara prinsip telah menjadi hak milik BMT maka selanjutnya bisa dilakukan akad kedua yaitu akad murabahah".(wawancara dengan Bapak Alif Hayat).

Secara konsep syariah, akad murabahah dan akad wakalah dsilakukan terpisah. Dimana akad murabahah hanya bisa dilaksanakan ketika barang sudah ada dan sah menjadi milik BMT (proses wakalah selesai). Hal ini dilakukan untuk mengurangi risiko penyalahgunaan dana oleh anggota.

Jika didasarkan pada fiqh maupun fatwa DSN MUI, akad pertama yang dilakukan adalah akad wakalah, BMT mewakilkan anggota untuk pembelian barang yang telah ditentukan. Setelah terjadi akad wakalah dan objek murabahah secara prinsip telah menjadi hak milik BMT maka selanjutnya bisa dilakukan akad kedua yaitu akad murabahah. Hal ini sesuai dengan fatwa DSN MUI Nomor 04/DSNMUI/IV/2000 tentang murabahah, dalam bagian ketentuan umum point 9 disebutkan bahwa jika bank hendak mewakilkan kepada nasabah untuk membeli barang dari pihak ketiga, akad jual beli murabahah harus dilakukan setelah barang secara prinsip, menjadi milik bank. Dengan 
kata lain, pemberian kuasa (wakalah) dari BMT kepada anggota, harus dilakukan sebelum akad murabahah terjadi.

\section{Analisis Praktek Akad Pembiayaan Murabahah di BMT Insan Samawa Berdasarkan Teori dan Landasan Hukum Syariah}

Menurut Ascarya (2011:81) murabahah adalah istilah dalam fikh islam yang berarti suatu bentuk jual beli tertentu ketika penjual menyatakan biaya perolehan barang, meliputi harga barang dan biaya lain-lain yang dikeluarkan untuk memperoleh barang tersebut, dan tingkat keuntungan (margin) yang diinginkan.

Jual beli murabahah adalah pembiayaan saling menguntungkan yang dilakukan oleh shahib al-mal dengan pihak yang membutuhkan melalui transaksi jual beli dengan penjelasan bahwa harga pengadaan barang dan harga jual terdapat nilai lebih yang merupakan laba atau keuntungan bagi shahib al-mal dan pengembaliannya dilakukan secara tunai atau angsur. Jual beli murabahah adalah pembelian oleh satu pihak untuk kemudian dijual kepada pihak lain yang telah mengajukan permohonan pembelian terhadap suatu barang dengan keuntungan atau tambahan harga yang transparan. Akad ini merupakan salah satu bentuk Natural Certainty Contracts (kontrak/akad) dalam bisnis yang memberikan kepastian pembayaran, baik dari segi jumlah maupun waktunya), karena dalam murabahah ditentukan berapa keuntungan yang ingin diperoleh.

Sedangkan menurut H. Abdul Rahman Ghazaly, M.A, (2010:89), jual beli merupakan bagian dari ta'awun (saling menolong).Bagi pembeli menolong penjual yang membutuhkan uang (keuntungan), sedangkan bagi penjual juga berarti menolong pembeli yang sedang membutuhkan barang. Karenanya, jual beli itu merupakan perbuatan yang mulia dan pelakunya mendapat keridhaan Allah swt. Bahkan Rasulullah saw. Menegaskan bahwa penjual yang jujur dan benar kelak di akhirat akan ditempatkan bersama para nabi, syuhada, dan orang-orang shaleh. Hal ini menunjukkan tingginya derajat penjual yang jujur dan benar. Ayat Al-Qur'an yang lain dapat juga dijadikan pedoman dalam murabahah yaitu Surat an-Nisa' ayat 29 yaitu:

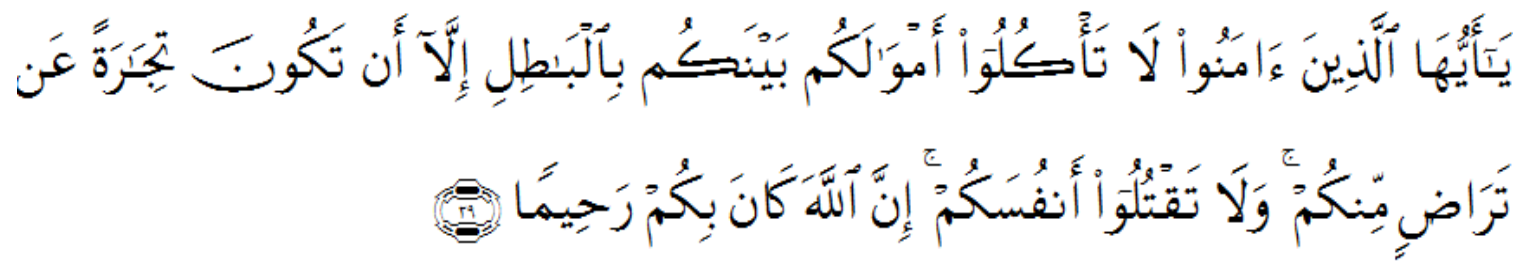


Artinya: Hai orang-orang yang beriman, janganlah kamu saling memakan harta sesamamu dengan jalan yang batil, kecuali dengan jalan perniagaan yang berlaku dengan suka sama-suka di antara kamu.dan janganlah kamu membunuh dirimu. Sesungguhnya Allah adalah Maha Penyayang kepadamu. (An-Nisa' [4]: 29)

BMT Insan Samawa merupakan salah satu lembaga keuangan syariah yang menerapkan sistem pembiayaan murabahah. Pembiayaannya meliputi: sembakao, pakaian, makanan, penjahit, loundry dan pulsa. Dalam pelaksanaan pembiayaan murabahah pada BMT Insan Samawa dilakukan dengan persyaratan yang telah ditentukan dan kesepakatan antara kedua belah pihak, apabila persyaratan tersebut telah dilengkapi oleh nasabah maka BMT Insan Samawa memberikan pembiayaan atau pinjaman dengan tingkat margin (keuntungan) yang ditetapkan pihak BMT dan atas persetujuan dari pihak pengaju. Hal ini menunjukan bahwa dari defenisi awal murabahah, BMT Insan Samwa telah seuai menurut teori dan landasan konsep syariah.

Jika dilihat segi perananan BMT Insan Samawa kepada nasabah saat akan melaksanakan akad pihak BMT memberikan edukasi terlebih dahulu tentang prinsipprinsip syariah dalam jual beli murabahah dimana nasabah harus mengikuti aturan syariah yang berlaku di BMT. Karena tujuan pokok BMT bukan memberi pinjaman dana tetapi jual beli murabahah. BMT tidak mau mengikuti kemauan nasabah untuk meminjam uang sebagaimana lembaga yang lain.Maka upaya memberikan pemahaman menjadi kunci pokok sebelum ditandatanganinya akad supaya nasabah mengetahui bagaimana prinsip-prinsip syariah murabahah dijalankan BMT. Apabila akad murabahah tidak tercapai maka BMT akan menarik diri dari akad atau mengarahkan nasabah dalam bentuk akad kerjasaman yang lain (mudharabah/musyarakah).

Fungsi BMT Insan Samawa adalah melakukan pembelian dan pengadaan barang yang akan dipesan nasabah. Dalam proses ini fungsi dominan BMT Insan Samawa sebagai pedagang dan penjual barang. Dikarenakan kewajiban bagi BMT untuk menyediakan pesanan dengan cara mencarikan barang sesuai kriteria yang diminta nasabah, baik kuantitas dan kulitasnya termasuk harga pokok dan biaya yang melekat pada barang yang dipesan. Seperti aturan fatwa DSN MUI bahwa untuk melaksanakan akad murabahah fungsi lembaga keuangan/ BMT tidak sekedar menyediakan penyaluran dana saja, namun BMT tetap mencarikan barang supaya terhindar dari gharar. Sehingga 
secara aspek prosedural pelaksanaan BMT Insan Samawa sesuai dengan aturan syariah. Karena dari aspek pencairan dana sampai pembayaran barang di stokis sembakao BMT yang membayarkan adalah pihak BMT sendiri.

Kedudukan BMT Insan Samawa adalah sebagai penjual dan nasabah sebagai pembeli, Alasan BMT Insan Samawa karena kedudukannya sebagai penyedia jasa maka, baik adan pesanan ataupun tidak fungsi BMT tetap sebagai penjual dan nasabah yang membutuhkan barang sebagai pembeli. Apakah laku atau tidak barang yang dijual adalah urusan Allah, BMT hanya sekedar menyiapkan barang dagangan untuk dijual pada pembeli (nasabah). Dilihat dari kacamata syariah BMT sudah menjadi penjual barang (seller) dan nasabah sebagai pembeli (Purchaser).

Proses transaksi BMT Insan Samawa memberlakukan dua kali tahapan transaksi, yaitu: 1) BMT membeli barang dari pemasok, dan 2) BMT menjual barang pada nasabah. Hal ini dilakukan BMT Insan Samawa untuk menghindari gharar atau ketidakpastian dalam kepemilikan barang apabila barang tersebut belumdimiliki utuh oleh BMT.Kalau barang belum dimiliki BMT maka, jual beli tidak bisa dilaksanakan.

Jika dilihat dari aspek persediaannya BMT Insan Samawa memiliki persediaan tidak hanya uang tapi juga barang. Dengan cara penyediaan stok barang baik ada pesanan barang atau tidak, karena fungsi BMT dalam murabahah adalah jual beli.

Aspek persedian berupa barang dari sisi syariah menjadi salah satu ciri dalam murabahah langsung bahwa BMT melaksanakan jual beli barang secara riil. Barang tersebut dimiliki BMT untuk persedian baik ada pesanan ataupun tidak. Adanya barang sebagai persediaan menjadi bukti bahwa jual beli dengan konsumen tidak selamanya berhasil namun kadangkala mengalami kegagalan dalam transaksinya. Penyebabnya biasanya karena nasabah tidak cocok dengan barang yang ditawarkan BMT. Maka atas dasar hak khiyar (memilih) inilah barang tersebut dikembalikan nasabah, sehingga menjadi stok persediaan BMT. Hal ini menunjukkan adanya aktivitas jual beli yang dilakukan BMT tidak hanya untung saja namun pernah mengalami kerugian. Berkaitan dengan alat bukti transaksi barang

BMT Insan Samawa yang memegang nota pembayarannya, kemudian diberitahukan kepada nasabah guna menghitung harga pokok pembelian dan marginnya. 
Kelebihan tentang alat bukti transaksi ini BMT mudah melakukan pengontrolan terhadap pembelian tidak ada rasa was-was dan keraguan.

Apabila dianalisa dengan aturan syariah, kemampuan BMT dalam mengontrol nota pembelian barang ketika barang yang mencarikan BMT seluruh proses pembelian akan terpantau secara langsung baik kualitas dan kuantitasnya termasuk bukti transakasinya.

Dengan demikian penulis dapat simpulkan pembiayaan murabahah pada BMT Insan Samawa pelaksanaannya sudah sesuai dengan konsep dan prinsip ekonomi Islam, dan benar-benar telah dilaksanankan sesuai dengan syariah Islam yang mana telah memberikan peranan penting dalam meningkatkan taraf hidup masyarakat terutama dalam pengembangan usaha mikro dan kepedulian dunia usaha terhadap peningkatan kesejahteraan masyarakat, pemenuhan kebutuhan masyarakat dalam menciptakan kesejahteraan umat.

\section{Catatan Akhir}

Berdasarkan uraian dan analisis yang telah dilakukan di Baitul Maal Wat Tamwil Insan Samawa maka dapat diambil kesimpulan sebagai berikut:

1. Prosedur yang harus dipenuhi oleh calon nasabah pembiayaan murabahah adalah dengan memenuhi syarat menjadi anggota atau nasabah BMT dengan mengisi dan menandatangani formulir aplikasi buku keanggotaan yang berisi identitas lengkap, calon nasabah harus amanah dan bertanggung jawab, setelah hal tersebut dipenuhi maka nasabah harus mengikuti prosedur yang ditetapkan oleh pihak BMT, seperti nasabah mengisi surat permohonan pembiayaan dengan standar akad dalam pembiayaan murabahah dan menyiapkan lampiran syarat-syarat pembiayaan seperti: a. Foto Copy Kartu Tanda Penduduk (KTP), b. Foto Copy Kartu Keluarga (KK), c. Foto Copy Surat Nikah d. Surat Persetujuan Keluarga dan bersedia untuk disurvey.

2. Proses pelaksanaan akad pembiayaan murabahah di BMT Insan Samawa sudah sesuai dengan konsep syariah, karena dilihat dari peran BMT Insan Sawama sebelum melaksanakan pembiayaan murabahah, terlebih dahulu nasabah dijelaskan bagaimana konsep syariah yang diterapkan di BMT Insan Samawa. Dari aspek persediaannya BMT Insan Samawa memiliki persediaan tidak hanya uang tapi juga barang. Dengan cara penyediaan stok barang baik ada pesanan barang atau tidak, karena fungsi BMT dalam 
murabahah adalah jual beli. Meskipun ada sistem wakalah BMT Insan Samawa tidak menyediakan fasilitas pinjaman dana secara langsung disebabkan rentan dengan riba, apabila wujud fisiknya bukan barang. BMT menyediakan barang untuk dijual-belikan kepada nasabah. Sehingga wujudnya dalam akad serah terima barang bukan uang.

3. Pembiayaan murabahah yang diterapkan oleh BMT Insan Samawa terhadap pengusaha mikro yang membutuhkan modal dalam pengembangan usaha sudah sesuai dengan konsep ekonomiIslam, dan benar-benar telah dijalankan dengan konsep syariah Islam,Sehinnga hasilnya memberikan peranan penting dalam meningkatkan taraf hidup masyarakat terutama dalam pengembangan usaha mikro dan kepedulian dunia usaha.

\section{DAFTAR RUJUKAN}

Al-qur'an dan Terjemahan: Juz 1-30, Bogor: 2016

Anwar, Syamsul. Hukum Perjanjian Syariah Studi Tentang Teori Akad Dalam Fikh Muamalat, PT Raja Grafindo Persada, Jakarta : 2007

Az Zuhaili, Wahbah. Fiqih Islam Wa Adillatuhu, Gema Insani Darul Fikir, Jakarta; 2011

Alfian, Pelaksanaan Akad Murabahah Untuk pembiayaan Modal Usaha, 2012.

Bungin, Metode Penelitian, Pustaka pelajar, Yogyakarta: 2013

Bilqis, Maulani, Analisis Praktek Pembiayaan Murabahah Untuk Modal Kerja, 2005.

Engkos, Sadrah. BMT, Bank Islam, Instrumen Lembaga Keuangan Syari'ah, Bandung: Pustaka Bani Quraisy, 2004

Ghufron, Mas'adi, A. Fiqh Muamalah Kontekstual, Jakarta : PT Raja Grafindo Persada, 2002

Ghazaly Rahman Abdul, H. Prof. Dr, MA. DKK; Jakarata;2010

Hirsanuddin. Hukum Perbankan Syariah di Indonesia, Pembiayaan Bisnis Dengan Prinsip Kemitraan, Yogyakarta: Genta Press, 2008

Huda Nurul, Heykal Muhamad, Lembaga Keuangan Islam, (Tinjauan Teoritis dan Praktis), Jakarta : Kencana, 2010 
Ismail, Habib, Analisis Pelaksnaan Akad Pembiayaan Murabahah Terhadap Peningkatan Laba, 2016

Irma, Devita, Tri Prakasa Lukita. Makalah: Murabahah Menuju Pembiayaan Yang Murni Syariah, Melbourne : 2006

Jafar, Anwar, Muhammad. Pedoman Praktis Penelitian,(Deleader, 2016)

Moleong, J. Lexy. Metodologi Penelitian Kualitatif, PT. Remaja RosydaKarya Bandung, 2013

Muhammad, Nadratuzzaman. Produk Keuangan Islam; Indonesia dan Malaysia Gramedia Pustaka Utama, Jakarta; 2013

Muhammad. Sistem dan Prosedur, Operasional Bank Syariah, UII Press, Yogyakarta: 2005

Mardani. Hukum Perikatan Syari'ah, Jakarta: Sinar Grafika, 2013

Rusyd, Ibnu. Bidayatul Mujtahid Wa Nihayatul Muqtashid, Akbar Media, Jakarta; 2013

Rasjid, Sulaiman, H. Fiqh Islam, (Sinar Baru Algensindo, Jakarta : 2013).

Sabiq, Sayyid. Fiqih Sunnah Jilid 4 (Pena Pundi Aksara, Jakarta; 2008)

Syafi'i, Antonio, Muhammad. Bank Syariah Dari Teori ke Praktik. Gema Insani, Jakarta; 2001

Sugiyono, Metode Penelitian Kuantitatif, Kualitatif Dan R \& D. Alfabeta, Bandung: 2104

Sugiyono. Memahami Penelitian Kualitatif. Alfabeta, Bandung: 2008

Sumarni, Murti. Metodologi Penelitian Bisnis. CV. Andi offsite, 2009

Widodo. Modal Pembiayaan Lembaga Keuangan Islam, Perspektif Aplikatif. KAUKABA, Yogyakarta: 2014

Wiroso. Jual Beli Murabahah, Yogyakarta: UII Press, 2005 